\title{
First roosts of Nyctalus lasiopterus breeding females in France
}

\author{
Marie-Jo Dubourg Savage, JoËl Bec and Lionel Gaches
}

\author{
Conservatoire des Espaces Naturels de Midi-Pyrénées/Groupe Chiroptères de Midi-Pyrénées \\ (CEN/GCMP), 75 voie du Toec, 31076 Toulouse Cedex 3 (France) \\ *Corresponding author e-mail: chirosavage@gmailcom \\ DOI: http://dx.doi.org/10.14709/BarbJ.6.1.2013.06
}

Spanish title: Primeros refugios de hembras reproductivas de Nyctalus lasioterus en Francia

\begin{abstract}
The studies on tree-dwelling bats were very scarce until recently, due to the difficulty of finding their roosts in forests. The Giant Noctule (Nyctalus lasiopterus, Schreber 1780) is one of those difficult forest species and probably the European rarest and least studied of them. However the development of bat detectors and of radio-tracking techniques have allowed increasing the knowledge on this elusive species.
\end{abstract}

Until recently, with the exception of a few occasional records of individuals, the Giant Noctule was mainly known from Spain and Central Europe where breeding colonies were located. We present here its distribution in France, where a colony of post-lactating females was found in June 2012. This record is the first documented data for Western Europe, north of the Pyrenees.

Keywords: Nyctalus lasiopterus, Midi-Pyrénées, Aveyron, breeding females.

\section{INTRODUCTION}

The Giant Noctule (Nyctalus lasiopterus) occurrence in some European countries is attested by skins in different museums, but very few facts on its biology and ecology have been published, and the available information comes mainly from Spain (Ibáñez et al. 2004, 2009, Popa-Lisseanu 2007, Popa-Lisseanu et al. 2008, 2009), Hungary (Estók 2007, Estók \& Gombkötő 2007, Estók et al. 2007) and Slovakia (Uhrin et al. 2006). However the most important ecological feature concerns its diet, as different studies have shown that the Giant Noctule is not exclusively an insectivorous bat, but feeds also on small migrating passerines (Dondini \& Vergari 2000, Ibáñez et al. 2001, Popa-Lisseanu et al. 2007).

With the exception of a young female banded in Spain and then found in Portugal (Rodrigues pers. com.), recovery of banded individuals is nonexistent, which means that the species status as a long distance migrant is not yet confirmed at least in Central and South-western Europe (Hutterer et al. 2005). However some probably migrating individuals were recorded at the Col de Bretolet in Switzerland (Arlettaz 1986 in Hutterer et al. 2005). The presence of sedentary males in the South, coinciding with the absence of females in summer, would also support the hypothesis of, at least, medium range migration (Helversen \& Weid 1990, Ibáñez et al. (2009), Beuneux et al. 2010).

The development of bat detectors and of automatic recording of calls has recently increased the number of Giant Noctule records, especially in France where this survey technique is widespread. However new identification problems are arising. Social calls of Nyctalus leisleri partly overlap 
Nyctalus lasiopterus echolocation calls (Bec et al. 2010a) but the main challenge is the overlap with Tadarida teniotis echolocation calls (Haquart $\&$ Disca 2007). This means that in areas where the European free-tailed bat is present, especially in the Pyrenees, older records of Tadarida based only on audio identification could have been Giant Noctule calls. Therefore, for French data presented on fig.1, acoustic identification was cross-checked by experts who analysed on computer the recorded call sequences.

If ultrasound recording is an excellent tool for bat surveys and impact assessment studies, it does not bring any information on the breeding status of the species that can only be assessed by mistnetting and radio-tracking. We present here the first results of a study in the département Aveyron (Midi-Pyrénées, south-western France). In this region, its presence was already documented by the capture of an adult male in September 2004 (Liozon 2004) on the river Viaur (Ségur, Aveyron) and of a non-breeding female in a beech wood of the same valley in 2010 on the limit of Ségur and Vézins-de-Lévézou (Bodin 2011).

\section{Study AREA ANd Methods}

The study area is located in the département Aveyron (administrative region of Midi-Pyrénées), on the Lévézou plateau between Rodez and Millau (fig. 2). This plateau with an average altitude of $900 \mathrm{~m}$ a. s. 1., consists of hercynian rocks (granite, gneiss and shale). Five large reservoirs that offer numerous activities to tourists are surrounded by hills called "puech".

The main river is the Viaur which takes its source at $1080 \mathrm{~m}$ a.s.l., at the foot of the Puech du Pal, the highest summit of the Lévézou (1155m), in the Parc Naturel Régional des Grands Causses.

Two large forests border the Lévézou: the Forêt des Palanges (444 ha) in the North, where firs and pines have more or less replaced the oak trees and the state-owned Forêt du Lagast (89 ha) in the South composed of beech (Fagus sylvatica) and silver fir (Abies alba).

Besides tourism the main activity is agriculture. Fields of cereals, hedgerows, pastures grazed by cattle and sheep contribute to forming a mosaic landscape, together with lakes, coniferous plantations and beech woods.
The highlands of the Lévézou are swept by high winds and new structures appeared recently in the scenery: wind turbines. In 2008 the first mortality cases for bats were reported on a single wind farm with 73 fatalities (LPO Aveyron 2009, unpublished report) and one year later 2 Giant Noctules were amongst the 98 victims of the same wind farm (EXEN \& KJM 2010).

It was then decided to try and catch Giant Noctule females to find their roosts, if any, by radio-tracking. Members of the Chiroptera Group of the Conservatoire d'Espaces Naturels de MidiPyrénées licensed for mist-netting bats were also authorized to equip a few individuals with radiotransmitters. The transmitters, type PD-2, came from Holohil Systems Ltd (Ontario, Canada). They weighed $2.9 \mathrm{~g}$, slightly more than $5 \%$ of the bat mass. They were glued between bat shoulders with DUO, a professional glue for eyelashes. Threeelement handheld antennas (type Yagi) were used with receivers "Australis" from Titley Scientific.

The trapping device consisted of three superposed mist-nets mounted between two $9 \mathrm{~m}$ high flagpoles. The mist-nets from Ecotone (Poland) were either $6 \mathrm{~m}$ or $9 \mathrm{~m}$ long according to the capture site and made of monofilament nylon (Ref. 08M/6 and 08M/9).

\section{RESULTS}

In 2012 , from June $23^{\text {rd }}$ to $28^{\text {th }}$ we tried to capture the Giant Noctule on the sites where it was previously mist-netted: the river Viaur in Ségur and in the beech wood close to the Viarouge wind farm. We could not catch any of them although they were passing regularly every night above the canopy. On June $29^{\text {th }}$ a promising site was found on the river. A ford with a beech wood on one side and pastures on the other was creating a large open space in the riverine vegetation and a pool of calm water $\left(44^{\circ} 15^{\prime} 39^{\prime \prime} \mathrm{N}, 02^{\circ} 55^{\prime} 05^{\prime}\right.$ ' E, $817 \mathrm{~m}$ a.s.1.).

Between 22:15 and 22:35 we caught 3 females at 1.50 to $5 \mathrm{~m}$ high. They were radio-tagged and released. Two roosts were found on June $30^{\text {th }}$, one $(\mathrm{N} 1)$ at $360 \mathrm{~m}$ from the capture site and the other (N2) at $1100 \mathrm{~m}$ in another wood. Both were woodpecker holes in beech woods but N1 was at $12 \mathrm{~m}$ off the ground in an oak tree (Quercus robur) and N2 $8 \mathrm{~m}$ high in a beech tree (Fagus sylvatica). The trunks were bare of branches below the holes, giving free flight access to the bats. The second 


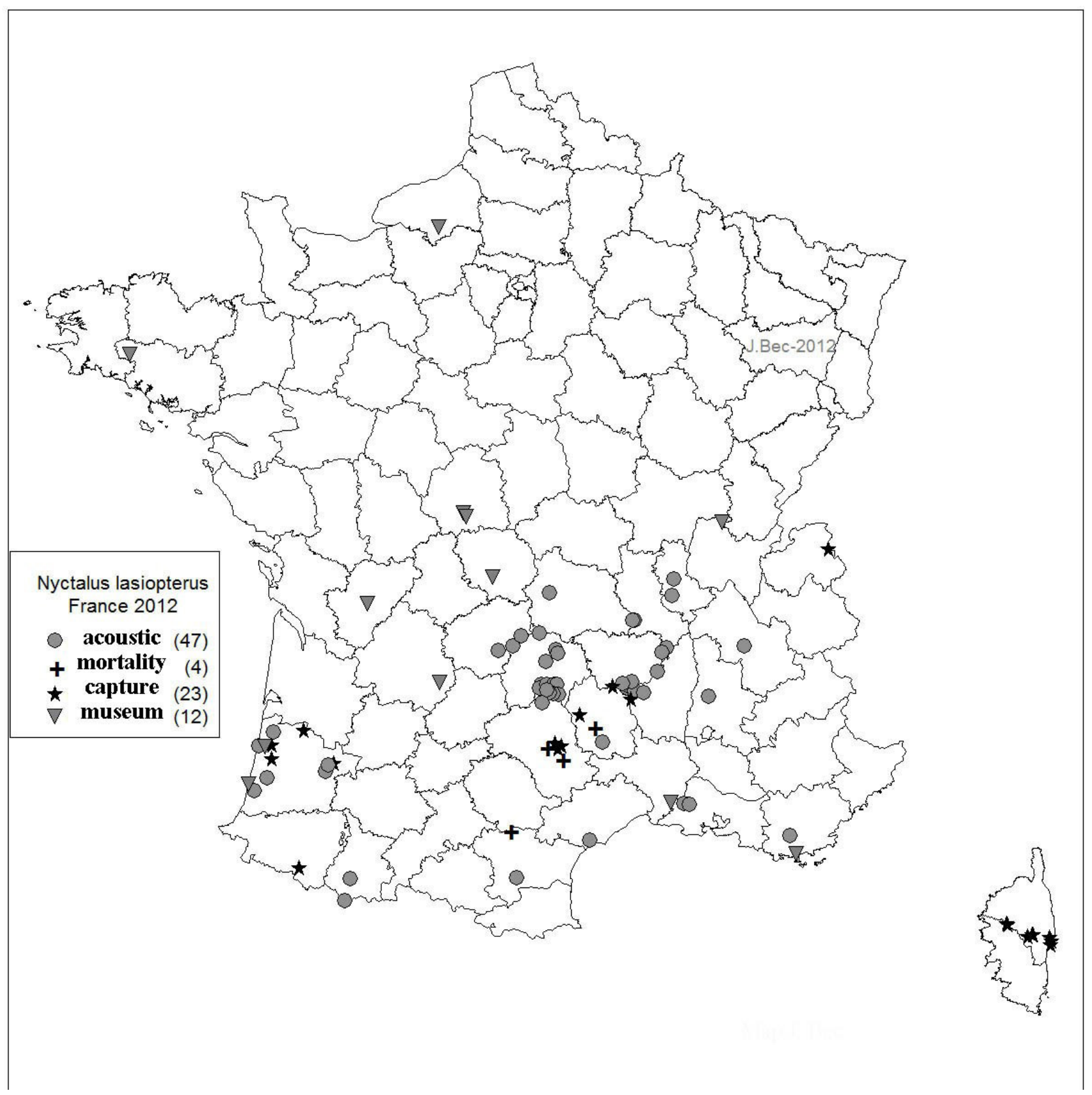

Fig. 1 Nyctalus lasiopterus data in France according to the type of contact

radio-tagged female (A2) was in N1, together with 14 other Giant Noctules. Females A1 and A3 occupied roost N2 with 18 other individuals. We also used a video camera for counting bats emerging from roost N1 (fig. 3).

On July $1^{\text {st }}$ a huge thunderstorm put an end to radio-tracking. Females A1 and A3 had already lost their transmitters, one at the base of the tree and the other inside the cavity and A2 had switched roost. It was apparently in a clump of 3 trunks with numerous holes and the exact roost could not be found.

Our aim was only to find roosts but we managed to get contact from 01:40 to 01:45 with female A1 when it flew towards the Viarouge wind farm and back in the valley. The same night A2 spent part of the night in a wood close to the mistnetting site and was observed at dawn flying out of it, then foraging above and in the vicinity of the ford from 5:30 to 5:45. This was the only homingin that we had.

On July $7^{\text {th }}$, five other post-lactating females and one adult male were mist-netted at the same capture site. On July $21^{\text {st }}$ and $22^{\text {nd }}$ it seemed that Giant Noctules had left the area as no signal was received from A2 transmitter and no ultrasonic contact was recorded near the ford. A last mistnetting session took place on August $28^{\text {th }}$ and we caught new individuals: 4 juvenile females, 


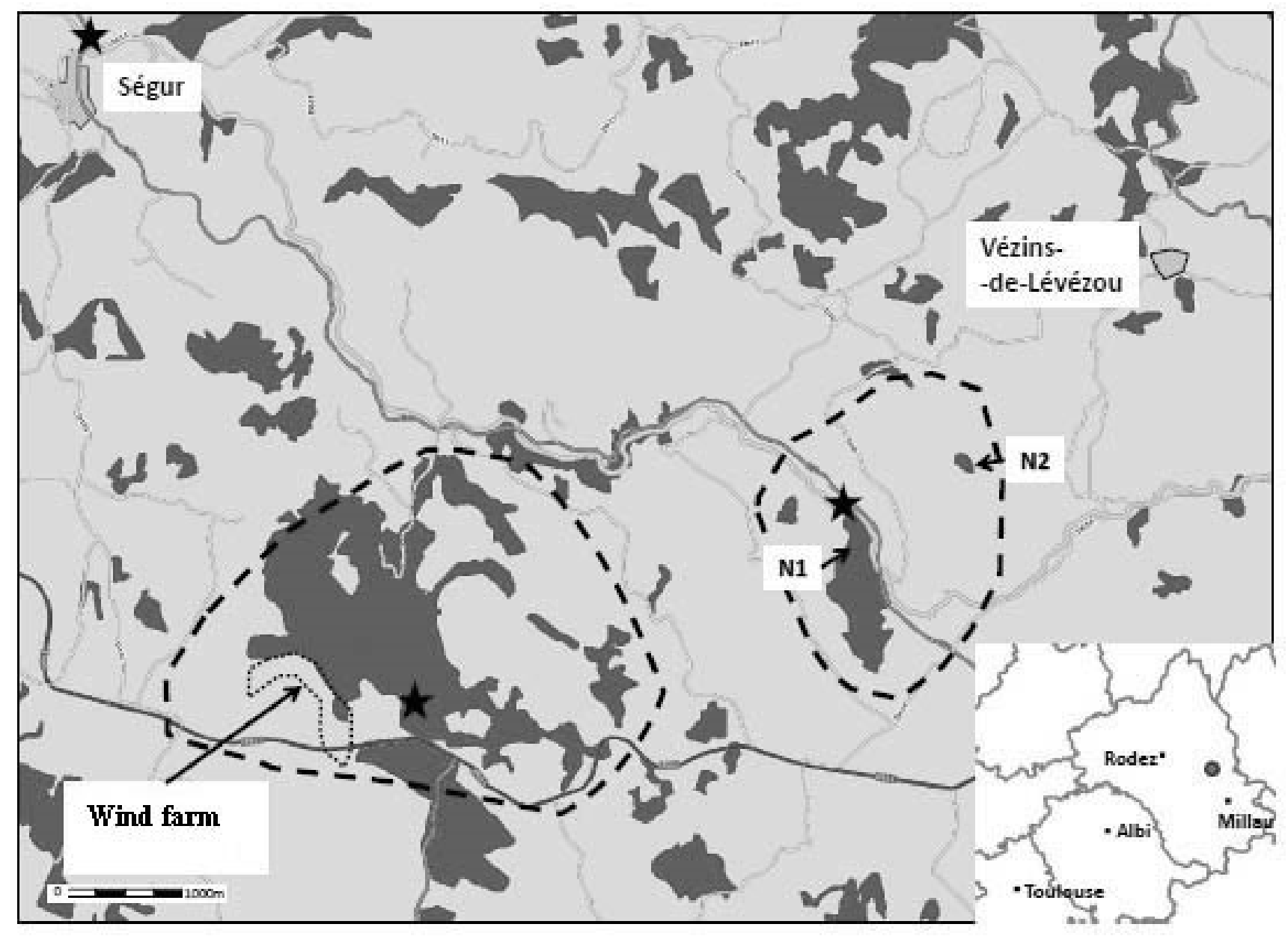

Fig. 2 Study area of Nyctalus lasiopterus in the Lévézou (Aveyron). The stars indicate successful capture sites (2004-2012); roosts are numbered, dotted lines show the areas of frequent contacts and the closest wind farm is outlined.

1 juvenile male and one post-lactating female. Biometry data are shown on table 1 .

\section{Discussion}

The discovery of 2 roosts of reproductive females in the Lévézou region confirms the presence of a small breeding population of Nyctalus lasiopterus north of the Pyrenees, in southwestern France. The first mist-netted females were identified as post-lactating as the skin around the nipples was bare and the nipples themselves were dry and flattened. But our attention was attracted by a peculiar detail that we had never witnessed on other bat species. The bare area around the nipples presented several dark crusts looking like mushroom scales, as if the young, trying to suckle, had bitten its mother.

The females captured on July $7^{\text {th }}$ showed also crusts, with the exception of one still lactating individual.
In Hungary, Estók and Gombkötő (2007) compiled all Hungarian data for Nyctalus lasiopterus and mentioned lactating females from July $19^{\text {th }}$ to August $31^{\text {st }}$, but they did not mention post-lactating ones and the only precise date for giving birth came from a captive female on 15.06.1960. In Southern Spain parturition occurs from late May to early June (Popa-Lisseanu 2007; Popa-Lisseanu et al. 2008). According to our data in the Lévézou region, it looks as if the postlactating females caught late June-early July could have given birth earlier and stopped lactating mid-June. May 2012 was a very wet month and June experienced a few cold spells in the region. Consequently numerous moth and large beetle species did not emerge that year or were very scarce compared to normal years (Dubourg-Savage, pers. obs.). This could have meant a lack of food for the Giant Noctule although the captured females were not underweight at the end of June. Unfortunately no mist-netting session could be organised from mid-July to August $27^{\text {th }}$ to check when young start flying in the area. 
Table 1 Some measurements of Nyctalus lasiopterus in summer 2012. Only females A1, A2 and A3 were radio-tagged.

\begin{tabular}{|c|c|c|c|c|c|c|}
\hline & Date & Sex & Age & Forearm & Weight & $\begin{array}{c}\text { Reproductive } \\
\text { status }\end{array}$ \\
\hline A1 & $29 / 06 / 2012$ & 웅 & ad. & 63,3 & 55 & post-lactating \\
\hline A2 & $29 / 06 / 2012$ & q & ad. & 67,5 & 57 & post-lactating \\
\hline A3 & $29 / 06 / 2012$ & $q$ & ad. & 65,1 & 55 & post-lactating \\
\hline B1 & $07 / 07 / 2012$ & q & ad. & 64.6 & 45 & post-lactating \\
\hline B2 & $07 / 07 / 2012$ & q & ad. & 66,5 & 48 & post-lactating \\
\hline B3 & $07 / 07 / 2012$ & q & ad. & 65,9 & 50,5 & post-lactating \\
\hline B4 & $07 / 07 / 2012$ & q & ad. & 67,5 & 60 & post-lactating \\
\hline B5 & $07 / 07 / 2012$ & 0 & ad. & 64,8 & 47 & - \\
\hline B6 & $07 / 07 / 2012$ & $q$ & ad. & 69,1 & 56 & lactating \\
\hline $\mathrm{CO}$ & $28 / 08 / 2012$ & $q$ & juv. & 62,2 & 38 & - \\
\hline $\mathrm{C1}$ & $28 / 08 / 2012$ & $q$ & juv. & 63,9 & 40 & - \\
\hline $\mathrm{C2}$ & $28 / 08 / 2012$ & $q$ & ad. & 65,4 & 50,5 & post-lactating \\
\hline $\mathrm{C3}$ & $28 / 08 / 2012$ & 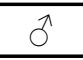 & juv. & 62,4 & 35 & - \\
\hline $\mathrm{C4}$ & $28 / 08 / 2012$ & $q$ & juv. & 65,1 & 37 & - \\
\hline $\mathrm{C5}$ & $28 / 08 / 2012$ & q & juv. & 64,9 & 48 & - \\
\hline
\end{tabular}

In this respect the species breeding phenology in south-western France needs to be clarified, as up to now 5 population nuclei have been identified, in the Landes département, the Pyrenees, the southern part of the Massif Central, the northern Alps and Corsica (Bec et al. 2010b). Further north, in the Massif Central, another Giant Noctule colony was found in July 2012 by following the individuals with an array of bat detectors and by hearing the animals chattering in the tree cavity. About 30 individuals were counted, but by the time everything was organised to capture and tag the bats, they had changed roost (Beucher pers. com.).

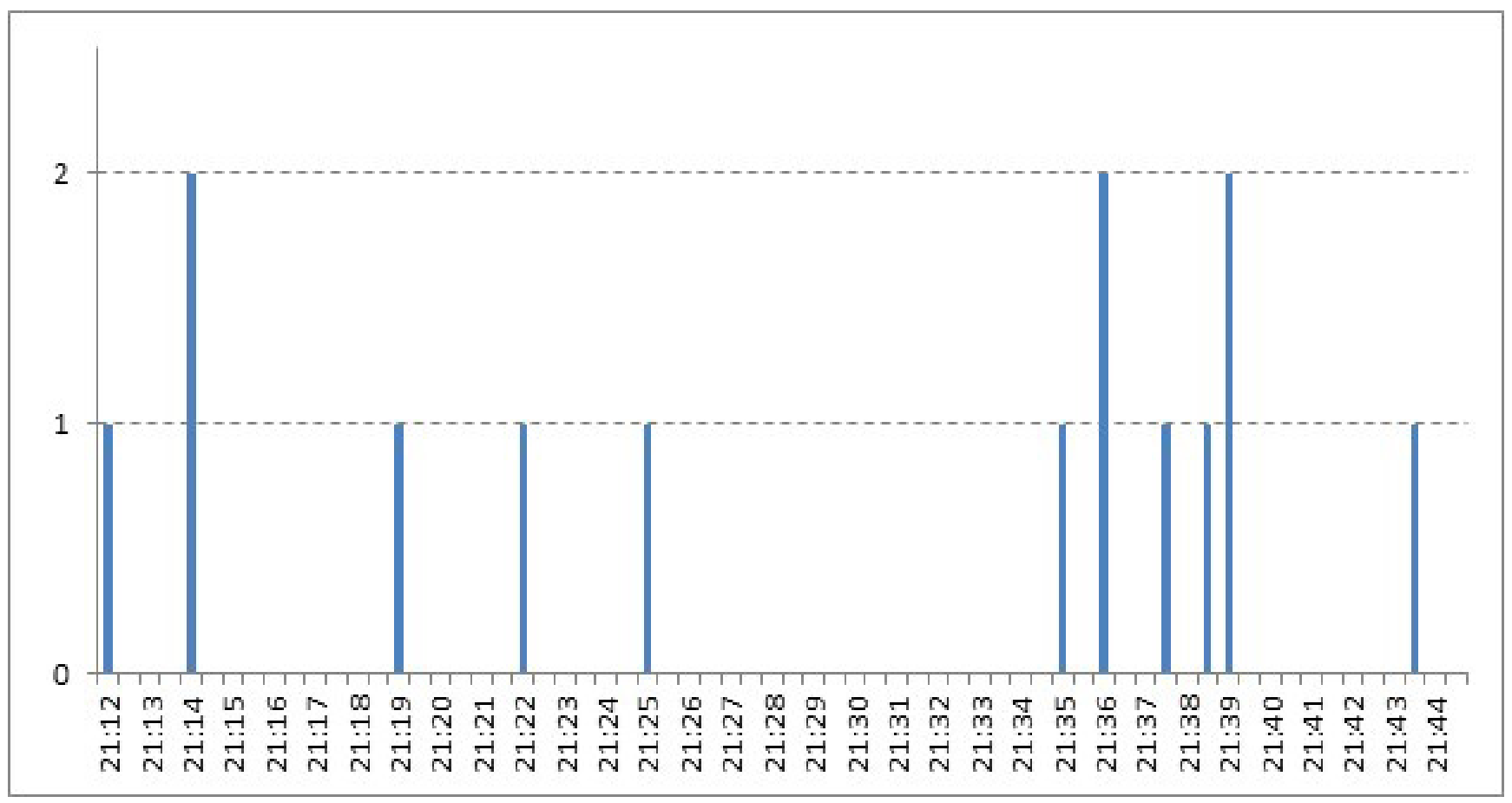

Fig. 3 Digital camera emergence count at roost N1 on 30.06.2012 at $30 \mathrm{sec}$. intervals. Radio-tagged female does not appear on the graph as it came out much later. 


\section{Conclusions}

Due to the new dangers that Nyctalus lasiopterus is facing in south-western France and to the lack of knowledge on its biology and ecology, the study of the small population found in the Lévézou should be complemented and the study area enlarged. It becomes essential to assess the period of the species presence and its nightly activity pattern. This is necessary not only to increase our knowledge on the species but also to try and reduce its mortality at wind farms by developing adequate curtailment algorithms taking into account season, wind speed, temperature and activity pattern.

Furthermore its use of the available foraging habitats and the density of potential roosts should be assessed before formulating conservation actions, e.g. giving recommendations for forest management.

\section{ACKNOWLEDGMENTS}

The authors are grateful to the numerous volunteers who helped finding and radio-tracking the Giant Noctule bat from 2010 to 2012. Without them this study would not have been possible.

\section{REFERENCES}

Bec, J., Haquart, A., Julien, J.-F. \& Disca, T., 2010a. New criteria for the acoustic identification of the greater noctule, Nyctalus lasiopterus, lead to a better knowledge of its distribution in France. Bat Res. News, 51(1): 12.

Bec, J., Haquart, A. \& Julien, J.-F., 2010b. La Grande Noctule, Nyctalus lasiopterus, en France : synthèse de sa répartition et hypothèse pour ses preferendum d'habitats. Symbioses, N.S. $25: 66-69$

Beuneux, G., Courtois, J.-Y. \& Rist, D., 2010. La Grande Noctule (Nyctalus lasiopterus) en milieu forestier en Corse : bilan des connaissances sur les arbres-gîtes et les territoires de chasse fréquentés. Symbioses, N.S. $25: 1-8$

Bodin, J., 2011. Les chauves-souris de MidiPyrénées : répartition, écologie, conservation. Conservatoire Régional des Espaces Naturels de Midi-Pyrénées - Groupe Chiroptères de Midi-Pyrénées, Toulouse, $256 \mathrm{pp}$.

Dondini, G. \& Vergari, S., 2000. Carnivory in the greater noctule bat (Nyctalus lasiopterus) in Italy. J. Zool., Lond., 251, 233-236. DOI: https://dx.doi. org/10.1111/j.1469-7998.2000.tb00606.x

Estók, P., 2007. Seasonal changes in the sex ratio of Nyctalus species in north-east Hungary. Acta Zoologica Academiae Scientiatum Hungaricae 53(1): 89-95

Esтóк P. \& Gомвкӧтö P., 2007. Review of the Hungarian data of Nyctalus lasiopterus (Schreber, 1780). Folia Historico Naturalia museui Matraeinsis, 31: 167-172

Estók, P., GombKötö, P. \& Cserkész, T., 2007. Roosting behaviour of the greater noctule Nyctalus lasiopterus Schreber, 1780 (Chiroptera, Vespertilionidae) in Hungary as revealed by radio-tracking. Mammalia 71: 86-88. DOI: https://dx.doi.org/10.1515/ MAMM.2007.007

EXEN \& KJM, 2010. Suivi évaluation postimplantation de l'impact sur les chauves souris en 2ème et 3ème année d'exploitation (2009-2010). Unpublished report

Haquart, A. \& Disca, T., 2007. Caractéristiques acoustiques et nouvelles données de Grande Noctule Nyctalus lasiopterus (Schreber, 1780) dans le sud de la France. Le Vespère 1: $15-20$

Helversen, O. von \& Weid, R., 1990. Die Verbreitung einiger Fledermausarten in Griechenland. Bonner zoologische Beiträge 41: 9-22.

Hutterer, R., Ivanova, T., Meyer-Cords, C. \& Rodrigues, L. 2005. Bat migrations in Europe. A review of banding data and literature. Naturschutz und Biologische Vielfalt, 28, 176pp.

IbáÑez C., Guillen, A. \& Bogdanowicz, W., 2004. Nyctalus lasiopterus (Schreber, 1780). Riesenabendsegler. In (F.Krapp, ed.) Handbuch der Säugetiere Europas. Vol. 4// II. AULA Verlag, Wiesbaden, Germany, pp. 695-716 
IbÁÑEz, C., Guillen,A.,Agirre-Mendi, P.T., Juste J., Schreur, G., Cordero A.I. \& PopALisSEANU, A.G., 2009. Sexual segregation in Iberian noctule bats. Journal of Mammalogy 90(1): 235-243. DOI: http://dx.doi. org/10.1644/08-MAMM-A-037.1

Liozon, R., 2004. Grande noctule en Aveyron. Kawa Sorix $2: 4$

Popa-Lisseanu, A.G., 2007. Roosting behaviour, foraging ecology and the enigmatic dietary habits of the aerial-hawking bat Nyctalus lasiopterus. $\mathrm{PhD}$ Thesis, Universidad de Sevilla, Sevilla: 142 p.

Popa-Lisseanu, A.G., Bontanida, F., Mora, O. \& IBÁÑEZ C., 2008. Highly structured fissionfusion societies in an aerial-hawking, carnivorous bat. Animal behaviour 75: 471- 482. DOI: https://dx.doi.org/10.1016/j. anbehav.2007.05.011
Popa-Lisseanu, A.G., Bontanida, F. \& IbáÑez C., 2009. Giant noctule bats face conflicting constraints between roosting and foraging in a fragmented and heterogeneous landscape. Journal of Zoology 278: 126-133. DOI: $\quad$ https://dx.doi.org/10.1111/j.14697998.2009.00556.x

Uhrin, M., Kaňuch, P., Benda, P., Hapl, E., VerbeeK, H.D.J., Krištin, A., KrištofiK, J, MašÁn, P. \& Andreas, M., 2006. On the Greater noctule (Nyctalus lasiopterus) in central Slovakia. Vespertilio 9-10 : 183-192 